\title{
Divisible Atoms Are Not Atoms
}

\author{
Stanislav Južnič \\ Dunajska 83, \\ Ljubljana 1000, Slovenia \\ E-mail: juznic@hotmail.com
}

\begin{abstract}
The aim of the article is to help change the self-contradictory term 'atom'. In this project, the support of modern Chinese scientists is expected. The contributions of Chinese to some researches in sciences are focused on finding out the preferences and most frequent stages of (European) paradigms involved in Chinese networks. Some predictions of future interests of Chinese sciences are provided. The Chinese holistic Confucian distrust in atoms is discussed as a possible new paradigm which could rename atoms as the destructible divisible entities of future physics, and with more difficulties also of chemistry.
\end{abstract}

The word 'atom' meaning an indivisible not a compound entity is basically in contradiction with the characteristics of the item it is supposed to describe. The suffix ' $a$ ( $\not \alpha)$ ' provides a negation in Ancient Greek language. The suffix

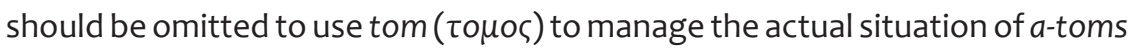
(toms) as compound of elementary particles. In the late 19th century after the European Spring of Nations, two basically different concepts of atoms of chemists and physicists accomplished a kind of symbiosis. The suggestion is put forward that while indivisible atoms soon became contradictions in physics, they still retain some value in chemistry, which should be important for the panning strategy of attempt to change the name of atom.

Keywords: 17 th-18th centuries, China, Confucian distrust in atoms, history of chemistry, history of exact sciences, Jesuits, scientific-industrial revolutions 


\section{Introduction: Presentation of research approaches of wrongly named obsolete atoms}

Our methodology compares physics and chemistry networks in different eras and areas to illustrate the great persistency of the term 'atom'. Our aim is to find the networks of modern sciences which could support the change of the illogical term 'atom'. Of all the discussed groups, modern Chinese researchers seem to be the most promising.

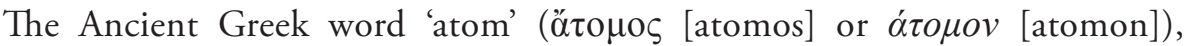
indivisible, not compound, a negation of tomos meaning cutting (from témnein, $\tau \varepsilon \dot{\varepsilon} \mu v \varepsilon l v$ 'to cut') does not correspond to its present meaning at all. In fact, it contradicts the essentials of the item that the denomination is supposed to describe. The unrigid concept of atom evolved a lot, but the very name of atom was never challenged enough although a century ago it became oblivious contradictio in adjecto which is still used just because its users do not understand the Ancient Greek language which makes atoms the divisible indivisibility. The words and names used are the most important, and the situation resembles

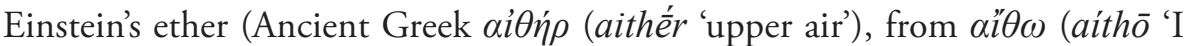
burn', 'shine'); Latin aethēr ('the upper pure', 'bright air')), which was similarly an Ancient Greek word. While ether looks like something divine, very far from Confucian thought, the atom sounds much more materialistic or earthly. Essentially, the atom is the negation of work of cutting and/or dividing. In May and December 1905, as well as in January 1907 and in April 1908 in Bern, the patent official Einstein made the things very funny with his discussion of the Brownian motions which provoked Jean Baptiste Perrin's and his student M. Chaudesaigues's groundbreaking atomistic experiments later in 1908 (Perrin, 1909). Einstein got rid of the unnecessary term 'ether' at the same time when he supported the other equally unnecessary term 'atom'. Did he realize that with his knowledge of Ancient Greek language or in 1919 ? conversation with his Greek colleague in Berlin, Konstantin Karatheodori (Carathéodory, 1873-1950), Einstein's approach was cautious in the first place before Ernst Mach's passed away. In all his thermodynamic publications of 1902-1908, and especially when Einstein discussed the botanist Robert Brown's motions of 1827-1828, he operated with the items named 'particles' or 'molecules' in the titles of his articles and avoided the term 'atom'. Einstein introduced the more neutral term 'molecules' (Latin Moles as 'mass barrier', 'mass unit', New Latin diminutive Molecula) of Descartes and Avogadro (1811) also in his work for chemists 
written on H. Lorenz' advice in April 1908. After Perrin's final proofs, Einstein, as the extraordinary professor of theoretical physics in Zürich, introduced the term 'atom' very cautiously in a compound word 'one-atomic molecule' in his title on November 30, 1910 and in his text for the first time in his reaction to William Sutherland's (1858-1912) publication in Phil. Mag. of the previous year. Einstein's colleague, the toxicologist Heinrich Zaggner (1874-1957), extraordinary professor of anatomy and special psychology in Zürich, brought this publication to Einstein's knowledge (Einstein, 1911, p. 170; Sutherland, 1910). In his British particle-dynamical traditions, Sutherland certainly used the word 'atom' without any hesitations. Several weeks before Mach's death in February 1916, Einstein used the term 'atom' freely in collaboration with few months older H. Lorenz's son-in-law Wander Johannes de Haas (1878-1960) at the Berlin Imperial Physical-Technical Institute on their validation of old Maxwell's idea of measurements of Ampère's good old molecular magnetic currents in 1915 (Einstein, 1908, pp. 235, 237; 1915; Einstein \& de Haas, 1915, p. 153). Einstein became the leader of Planck's chemical-thermal research frame against the particle-dynamical traditions of the Cavendish laboratory of $\mathrm{J}$. J. Thomson and Rutherford. In 1903, Einstein still endorsed Heinrich Hertz's doubts in the applicability of the concepts of force in mechanics but in the theory of heat Einstein did not share Hertz and Kirchhoff's doubts about the applicability of molecular-atomic theory. Einstein wished to unite formalistic thermodynamic of J. Fourier's type with Clausius's kinetic theory of particles. Einstein and his father wrote several letters to W. Ostwald and Einstein seriously reconsidered Ostwald's energetics, including the latter's (and Mach's) critiques of the classical physics at least up to 1903 (Gearhart, 1905, p. 473).

In 1905, the reason why Einstein, Mach, Ostwald, and other fellows were cautious was the invisibility of unmeasurable particles and not their apparent composition. The reason as to the term 'atom' was not abandoned after its composition appeared convincing was that the nineteenth-century struggle for atoms was so fierce and so recently won that the change of particles' name from atom to something more appropriate could sound like the vindication of just abandoned concepts of anti-atomists, whose camps even W. Ostwald left after Perrin's experiments. It was never safe to criticize a recent winning concept with the third one too soon because the third concept may look suspiciously like the abandoned first one in a kind of dialectics.

Another reason for keeping the strange divisible-indivisible atoms ashore might be their Hellenic patina. The European Renaissance passion for Hellenism, 
which enabled Rudolf Clausius to coin so many Greek phrasemes for physics, was the reason why the name 'atom' is still so welcome despite the fact that everybody knew that the particles called indivisible atoms are divisible. With J. Dalton, the term 'atom' eventually entered physics and chemistry as a modern European world which quickly lost its Hellenistic roots. When the divisibility of particles called atoms was decisively proved after Rutherford's bombarding of the nucleus and after numerous particles-resonances popped up during the Cold War, nobody could change the popular nonsense name of particles-atoms any more, like nobody was willing to change Franklin's nomenclature of plus and minus electricity, which forced poor electrons to fly backwards in the wires.

Soon after Dalton and Avogadro it became certain within modern particle physics that atoms are divisible. Therefore, the word 'a-tom' should be at least changed to 'tom' or even better to 'Tom', meaning 'a small Thomas'. Because the atoms really are very small. It is just the question of ' $a$ ' in its first place, even 'Tom-a' could work, indeed.

In chemistry, it is a little different because the chemists do not go far into the structures of atoms except for their interchanging of electrons.

\section{Community addressed that could change the illogical term 'atom'}

To change the name of the item we used to call atoms for several millennia would mean to change the paradigm behind it. To manage that, the truth about the contradictory term 'atom' is not enough, we also need some "political" support from the leading scientists. To achieve such a fundamental goal, we should examine how the funny concept of atom entered the (modern) physics, chemistry, and related fields in the first place. The early modern and contemporary networks of atomists should be carefully examined to figure out how to persuade the top modern academicians to allow the replacement of the word 'atom' with a more appropriate term. Certainly a hard job to accomplish single-handedly, but at least worth a try. Nomen est omen, as the Ancients knew very well. To change the name of atoms it would mean to change the human vision of the world which the atoms form as well as the worlds within the atoms. We hope to get decisive help towards those goals from the traditional Chinese Confucian beliefs of divisibility of all items, including those which naughty Europeans used to call atoms. 
Which networks are we facing and addressing with our proposed change from 'A-tom' to 'Tom'? A recent analysis proved that two-thirds of two hundred thousand listed mathematicians in North Dakota Mathematical Genealogy Project belonged just to 24 academic trees of the physician Sigismondo Polcastro (1384-1473) of University of Padua, the Russian Ivan Dolbnya (1853-1912), D'Alembert (1717-1783), Leibniz, the Englishman Henry Bracken (16971764), and several others. The Slovenian Jurij Vega with his 6,008 academic descendants was one of the leading teachers worldwide. A great part of his academic descendants are modern Central European and especially Slovenian mathematicians and physicists. While several Bohemian Jesuit mathematicians like Ignatz Mühlwenzel, Stepling, or Tesánek are part of the Mathematical Genealogy Project, Jakub Kresa (1648-1715, Brno) and most Habsburg Jesuit mathematicians, including Ernest Vols (1650-1720, Vienna), are not, despite the fact that they were very prolific teachers with thousands of academic descendants.

The main thematic shifted from applied mathematical physics of the industrial revolution, through code-breaking of the Second World War into modern computer sciences. Austria and Hungary lost a lot of their prestige after their Habsburg monarchy collapsed in the First World War, while their antagonist Soviet Union advanced. The German predominance in $\mathrm{PhD}$ production shifted from Germany to the USA after Jewish Holocaust exodus. Japan and India immerged after the war, and Brazil with China advanced in recent decades following the Russia, and USA's decline. This research provided no attempt to adapt to the dynamic changing of borders of states but used the modern situation instead. The use of the most prolific dissertation adviser as the only relevant academic ancestor is also debatable. The fact that mathematicians have much better academic tree project compared to other fields of research relies on the idea that the fame of a mathematician usually depends on his teachers and collaborators, and much less on his publication and citation index, which are relevant in most other fields of research (Castelvecchi, 2016; Gargiulo et al., 2016, pp. 3, 9, 11, 14).

The contributions of a researcher consist of his/her industrial-technological, experimental and theoretical parts, although there was never an explicit border between them. We can put together the assessment based on preserved portion of his or her technological innovation, economic-political impact, and potential of teaching. Kircher, Einstein, and several other eminent scholars worked in the number of branches of physics. Per definition, the Chinese scholars are those who worked for two or more years in the territories populated by Han Chinese 
or were born in these areas. The strange persistence of the European term 'atom' reflects the conflicts of Western and Eastern views. If we want to stimulate the allies to help us change the term 'atom' with a more appropriate one, the Chinese might be the right choice. Let us look at their modern era approach to Western scientific ideas, including the atoms.

\section{European missionaries in China}

The Austrian Jesuit Province educated a number of China-based Jesuits. Avguštin (Augustine) Baron Hallerstein was probably the very best and last of them, but he stood on the shoulders of his giant compatriots. China was not their only choice because even Hallerstein judged similar offers from India-based observatories during his preparation months in Portugal. His maternal uncle Innocent Baron Erberg worked in the South American reductions, therefore neither China nor the Far East were their only love. In fact, they loved distances and the sacrifice of missionary work. That kind of feeling and passion was far from the ordinary one. Most of the Jesuit missionaries knew they will never return to their homes, and A. Hallerstein with his awful seasickness was certainly one of them. What was so special about those folks? There is just one answer-the perfect missionary training which they received in their native European colleges prepared those missionaries to love the prosperity of their Jesuit order much more than their own lives. In other words, their lives were identical with Jesuits' networks. They were an acting part of a centralized semi-military worldwide organization.

The Franciscan friar Odoric of Pordenone (Mattiussi, c. 1286 in Villanova near Pordenone of Friuli to 1331) might be one of the first men of Slavic descent who visited China and Tibet. A decade before his birth, the Habsburgs bought the Pordenone area as their enclave in the properties of Patriarch of Aquileia. There were ancient Roman villas in the area, but the Slavic element was dominant in Friuli of Odoric's times. Pordenone got the status of the city when Odoric was already in the Far East. In 1318, he travelled to the Far East and dictated his memories upon his return to Udine in 1330 as a relevant addition to Marco Polo's earlier stories.

Three centuries after Odoric, the Jesuits of his neighboring Carniola followed his footsteps, although most of them preferred their sailing to inland journeys. The first of them, Bernard Diestel (1623-1660), was born in Vipava, $130 \mathrm{~km}$ 
east from Odoric's home. Diestel inherited the nice Odoric's habits of inland travel, but he was not happy enough to return to his home areas. Diestel's famous Vipava countryman Sigmund Knight Herberstein (1486-1566) certainly also traveled inland, but he had no other opportunities to reach Russia.

Johann Baptist Mesar (Messari, 1673-1723) was born near Branik some 26 km west of Diestel's birthplace. The family of Avguštin (Augustine) Baron Hallerstein (1703-1774) used to have some property near Planina (Haasberg) and Koča Vas near Lož (Laas), but Avguštin himself was already more inclined to the Upper Carniola near Ljubljana in his father's castle of Mengeš and in his mother's, Baroness Erberg's castle of Dol by the Sava River. While Odoric, Bernard, and Avguštin died in comparative peace, Johann suffered a lot in Hanoi.

There is something special about members of a small nation who wish to save the members of the far-away, a thousand times greater nation from their supposedly wrong faith. Or, in Jesuit interpretation before they lost the Chinese Rites Controversy, from their absence of any faith. The leaders of the great nation do not have much fear about them, as the Chinese Emperor decided to accept the Portuguese Macao and the Portuguese Jesuits because he learned that the Portuguese army was quite incapable of attacking China. The Habsburgs Jesuits were not allowed to enter China's mainland, so they traveled under the Portuguese flag.

\section{Chinese for Europeans}

To determine the Jesuits' Chinese motifs we studied their European backgrounds. Most China-based Jesuits sailed away from Europe in their thirties, as completely formed priests ready to challenge basically different advanced cultures. They carried two weapons with them: strong beliefs based on a strict hierarchy of the Catholic Church with the military Jesuits' exclusiveness in the very heart of it, and the knowhow of science and technology, ready to please their new hosts as a way to win their souls for the Christianity. In fact, the Jesuits themselves were the weapons of the Jesuit General, ready to do everything and more for the greater glory of their order. The Central European Jesuits were even very willing to go to the Northern Serbian Turkish battlefields where most of them died young of bullets or sables with their bones buried under the Kalemegdan fortress of Beograd (Belgrade). 
As hierarchically-minded newcomers, the Jesuits became very obedient servants of the Chinese Court. They disliked several facts in their new home, described their frustrations in their private enterprises and letters, but officially always behaved their best except for their preaching in forbidden Chinese areas, which brought some anathemas and even death penalties on their heads. Mesar and his fellows just could not resist the dangerous opportunity.

When Dr. Prof. Mitja Saje presented the English translation of our book about Hallerstein in 2014 in Beijing (Saje, 2014), a Chinese Europhobic scholar stated that Hallerstein was a spy. Mitja was very upset and he authorized the present author to defend Hallerstein's honesty. The present author wrote a few paragraphs to protect Hallerstein's glory, but later he at least partly changed his mind. No defence is needed, because both parties were right. In fact, the Jesuits who were based in China were the perfect double spies. They mailed information about China to Europe, and at the same time they explained the European matters, including new advances in military technology to the Chinese. Their seemingly strange double role did not bother them much, they felt in it as fish in water. They served two or more masters, the Chinese Emperor on the one side, and the Pope, Jesuit General, their European noble founders, Portuguese king or the Habsburg Emperor, on the opposite side. The Beijing and Roman authorities were extremely distant from each other with no hard feelings or even war between them on the horizon. The Jesuits were not really sitting on two chairs. Their position seemed to be very natural except during the Chinese Rites controversy, incited by the Catholic enemies of Jesuits, which was the first major Jesuits' defeat after two centuries of their history full of victories. In fact, the China-based Jesuit missionaries, including Verbiest, were ready to serve the Chinese Emperor even in the military fields, and their Catholic religion was their only obstacle in their transformation into full-blood Chinese. Except for the Chinese Rites controversy, there was no need for them to choose sides because the Chinese-European antagonism emerged only after the Lord George Macartney's mission of 1793 which culminated in both Opium Wars 66 years later. No Jesuit missionary before the suppression ever predicted the future wars between Chinese and Europeans, therefore the Jesuits loved both of those parts of Eurasia with the same heart: they adored Europe as their mother who gave them life and education, and they respected China as their father who gave them the opportunity to distinguish themselves. They had two fatherlands and in case a hypothetical war would break out between them in the mid- $18^{\text {th }}$ century, they would not know which side to support 


\section{European preparation for Constantine's scenario}

The drill of a Jesuit to prepare for his devoted work lasted for a quarter of century. With a monopoly in most of the Catholic middle schools and universities, the Jesuits were able to choose whom to accept into their order. The intelligent Jesuit teachers were able to convict any teenager to join their order in a system of schooling that had no match in European history. Many parents feared that their boy could join the Jesuits, and some were afraid enough to take their youngster from the Jesuits' school prematurely, as for example the parents of Alessandro Volta. Others tried to do so but failed, such as for example the Habsburg Balkan officer of Swedish origin, the father of the famous Jesuit botanist Franz Xaver von Wulfen. The Jesuits themselves posed some limits to their school propaganda and usually did not want to interfere with the life decisions of the highest nobility, for example of the counts and princes of Auersperg. They would have liked to, but they knew that it could bring many troubles, because the highest nobility was predestined for the highest offices in Europe and the Jesuits did not have a lot of those on their disposal. For that reason, no prince in Central Europe ever joined the Jesuit order, but several counts did. The Jesuits kept those members of highest nobility outside their order but still very close, helpful, and susceptible to Jesuits' political pursuits.

In China and other missionary lands, the Jesuits behaved somewhat differently because the opinions of local highest nobility were their primary goal. They wished to convert those elites to Christianity, but never pushed hard to make the top officials members of the Jesuit order. Such membership could eventually become counterproductive, because the high nobility would demand the highest posts in Jesuits' hierarchy, while the Jesuits wished to keep those for the white Europeans whom they trusted more. Eventually, no seventeenth-eighteenthcentury Pope would confirm the Chinese Native Jesuit on the position of bishop, especially not after the Chinese Rites controversy. The Jesuits were quite willing to accept in their order members of the well-educated ruling network, but not the most powerful of them, and even sent some of their Chinese fans to study in Europe. The Jesuits needed the converted local highest nobility for other purposes, because they dreamed about the new Constantine the Great (272/273-337), who gradually converted the whole Roman Empire from top to bottom. In his vision of 312 and in the toleration Edict of Milan of 313, the smart and devoted Constantine felt that Christian religion was the best available tool to keep his Pax Romana working, so he began to replace the old-fashioned 
Roman gods with the Christian God in the new state religion. He supported the new ruling-administrative class of Christians and moved the political center from Rome to the second Rome called Byzantium-Constantinople to smooth the changes. In Arnold Toynbee's visions, such a move of capital always designates the direction in which the state wants to expand, or it wishes to stay peaceful if the chosen capital is in the centre, such as Moscow or Bonn. The capitals moved from Krakow to Warsaw, from Nanjing (Nanking, 1368-1421, 1912, 1927) to Beijing and back, from Istanbul to Ankara, or from Russian Moscow to Petersburg and back. The move of the capital from Rome to Constantinople designated the abandonment of Roman dangerous plebs' Panis et Circencis, as well as a wish to share Greek culture and to be nearer to Jesus' Palestine. In 1920-1923, Mustafa Kemal Atatürk's (1881-1938) moved the capital from Istanbul to more central Ankara to announce the end of Turkish expansion into the Balkans during the rearranged imperialists' circumstances (Toynbee, 1962). Certainly, Arnold Toynbee's vision of evolutional combats for survival of the fittest civilizations or churches cold be applied to the scientific paradigms, as well to the competition of languages, where Arabic finally outrooted Egyptian with some remains in Coptic worshipping, Persians and Arabs borrowed Aramaic scribes and writing, Galileo and Descartes' Discours de la méthode (1632) deprived Latin of its primacy after Oersted's Latin announcing of electromagnetic discovery (1819), the Sumerian language after the defeat in its own territory survived in religion and learning, and the written Sanskrit of nomadic royal camps, which was probably never spoken, was given the same function in India. Several languages like Albanian or Indo-European Romani in Armenia borrow widely from the neighboring groups, while the East European Gypsies remain bilingual. Modern scholars exceed the limits of linguistic evolution and grammar with nonlinguistic sets of symbols such as mathematical formulae (Cohen, 1947, pp. 82, 83, 91, 93, 95, $131,137)$, which are like a kind of transnational civilization or church of their own.

In his ocean of predominant Latin with some Greek language, which he did not master well, Constantine was happy enough to rule for a quarter of a century after his first public decisions in favour of Christians. During that era, he developed a new caste of Christian administrators which soon forced most of their compatriots to accept the conversion because without it there was no promotion in the state administration. The membership was a ticket to higher posts in state bureaucracy, the winning scenario which the Ottoman, the other Muslim and communist regimes adopted later. After Commodore Perry's threat in 1853, the Japanese islanders' conversion to European frames 
was slightly different because no Christianity or similar Japanese membership was necessary and only commitment to the new norms in the spiritual sense was needed, as well as the loyal obedience to victorious USA. In contrast to Constantine's Pax Romana or Muslims' states, the Japanese had the unquestioned independent centralized state which was able to issue the edicts like the "overnight" abandonment of the traditional Japanese mathematics wasan (和算) for yozan (Western mathematics) in Nagasaki Naval Academy (1855-1859) and more decisively with a code entitled Gakusei (学制) on June 12-August 4-September 4, 1872. Later, similarly overnight, the Japanese authorities ordered a strict timing of work and related processes all around their country. Certainly, the old-fashion Japanese did not change overnight, similarly to Constantine's Christians who did not assume power overnight.

Before the suppression of 1773, the Jesuits tried to follow the same Constantine's scenario in China, and later in Russia the Jesuit general Gabrijel Gruber almost converted Tsar Paul I. In China, the Jesuits advanced with conversions of the locals to Christianity, sometimes millions of them on a single great occasion. The intermediate persecutions in Pax Romana before the Constantine's edict of Milan (313), as well as in China, convinced the Jesuits that even the majority of converted locals could not bring the steady victory which only the ruler's love of Christianity could guarantee. The multitude of Christian locals were only the condicio sine qua non. Without the public support of the ruler, the Christian community was always vulnerable as a subject of possible heavy persecutions, no matter how numerous the community should be. So, every new Chinese Emperor was a potential Constantine in the imaginations of hopeful Jesuits. They fought so bravely in the Chinese Rites controversy because they knew that the Emperor could (secretly) convert, or at least became inclined, to Christianity only if the Christianity could be presented to him as something very close to the Confucian doctrines which he practiced. In fact, the formal conversion to baptism was not necessary because Emperor Constantine avoided it as long as he could, and the Catholic baptizing of Tsar Paul I could be a disaster because he was also the head of the Orthodox Russian Church, and the baptizing of Chinese Emperor might question his rule as the leader of Confucian ceremonies. The formal baptizing of the key members of court administration was the way to the victory with a tolerant if not converted ruler at the top of it.

The change caused by the conversion to Catholicism should be huge in the matter of soul and eternity, but small in the customs and politics where no Jesuits nor the Emperor wished to provoke any great revolutions. The reality 
was much more different. The Jesuits never quite understood that the China had fundamentally different traditions compared to Europe of Constantine and even of Paul I. Ignaz Kögler, predecessor of Matteo Ricci and Hallerstein, studied the Jewish presence in China and concluded that several Jesuits were involved in the search for the ten ancient lost tribes of Israel which supposedly traveled to the east from the Middle East basin. The Jesuits were determined to find connections with their supposedly true religion to build their Catholic Chinese church on its fundaments. The Europeans and their Jesuits among them were never able to treat other religions as equivalent to Christianity. They accepted a form of ethnocentrism that never ceased to dog the minds of Westerners in sense of Einstein's definition of racism as the disease of the White Man (Jones, 2009). Einstein wanted a mutually connected world of causality despite of his opponent Niels Bohr's quantum mechanics trends.

The fight for souls in China was unbalanced and sometimes cruel. Millions of Chinese were converted to Christianity and almost no Europeans were converted to any of Chinese forms of beliefs including Confucianism until the modern era. The strange outcome was certainly caused by the aggressiveness of the Jesuits and other missionaries, which was made somewhat politer only with Matteo Ricci's method of adaptation. The aggressive Catholic ways could be compared to Muslims' need to convert the others, but even the Muslims tolerated the "infidels" and just taxed them more than the Muslims in the same area. The aggressiveness and racism enabled Europeans to achieve apparent success in Latin America, Australia, Pacific Islands, or South Africa, but it brought no permanent luck to the European aggressors in the solid traditional states of China or their Japanese neighbours. Even the European-British apparent victory in India with no contemporary strong overwhelming state after Muslim invasions was just a brief event during the times of troubles in Indian Subcontinent. The states of China, Japan, or India had the millenniums of histories and the era of European dominations was merely a short episode in these. The same goes for Egypt, PersiaIran, or the modern tragedy of Mesopotamia-Iraq, despite the fact that Muslim rule of the last millennia somewhat changed the linguistic situation there with the introduction of (classical) Arabic language and Islam. 


\section{Industrial-scientific revolution: why did it not happen in China?}

The European misunderstanding of non-Christian religions is combined with the European misunderstanding of non-European industrial-scientific revolutions. Craig Martin of Oakland University and many other scholars born after the 1960s disliked the concept of scientific revolutions simply because it was repeated too often after Thomas Kuhn's initial success. It went far beyond Kuhn's physics into humanities. The concept certainly lost its appeal with the closing of the 2nd millennium. ${ }^{1}$ The 1968 flower-power sexual revolution met the end of its momentum, the Soviet Union revolutionary traditions collapsed with their state itself, and the concepts of revolutions were obliviously temporarily replaced with the fans of evolutions.

Who invented the foolish European-centric question about the apparent failure of the Chinese to develop their own industrial-scientific revolution before Europeans? The defeated Chinese posed the humiliating question about the nonexistence of their domestic science in the European context to themselves in late 19th century, culminating with the work of Yu Lang Fung (馮友蘭,冯友 兰, 1895-1990) shortly before he received his $\mathrm{PhD}$ at the Columbia University in 1923. Fung stated that early modern Europeans developed the techniques to control matter, their contemporaneous Chinese developed techniques to control mind within life, and the Indians developed techniques to control mind in the negation of life. While the medieval Europeans searched for happiness in heaven, the ancient Greece and modern Westerners tried to find it on earth, but the Chinese wanted to find good and happiness directly inside their human minds. The Chinese wanted to conquer themselves and for that purpose they needed no exactness of scientific measurements (Kim, 2004; Fung, 2016[1934], p. 39) in the times before measurements and statistical methods embraced the psychological research. In fact, the Chinese philosopher Fung finally concerned himself with the scientific questions of Immanuel Kant (1724-1804), the heavily criticized subjective idealist Johann Gottlieb Fichte (1762-1814) who refused Spinoza while promoting dialectical pioneering approach to philosophy of science with eternity (Fichte, 1974, pp. 36, 68, 146-147, 152), or Fung's younger contemporary positivist Karl Popper (1902-1994). In that way, Fung's philosophical concern for his humiliated country initiated the postponed birth

1 Personal communication with Craig Martin during our joint Mellon fellowships at Oklahoma University in 2009. 
of Chinese science of the European kind: no more concerned with the mind but with the matter, no more introversive but extroversive. Basically, that was what Fung was up to as an American-educated Chinese patriot who suffered all the local trauma of the Cultural Revolution just to be able to stay in his home country. Fung stated that China has no science and many Chinese literati followed his cry. In fact, the Chinese supported no atoms and because of that it looked like lacking a whole bulk of science with Hui Shih's (350-260 BC) ultimately small which had no form, and ultimately big which had nothing to be surrounded with (Fung, 1934, p. 112).

The origin of Fung's question and its prevailing self-evident European-centric answer was certainly Jesuit-based, as was the idea of Chinese atheism or the idea of atheism itself, which were all products of Jesuits' scholarship. With the term 'atheism' the Jesuits wished to differentiate the Chinese from other weaker nonEuropeans whose beliefs also did not match the European criteria for religion. Three centuries before J. Needham, the Jesuits proved the existence of advanced Chinese technical and scientific knowhow of previous centuries so well that even Leibniz, in his unfinished tractate of 1715/16 (Leibniz, 1715), and other Europeans became the fans of China's political and correlated systems. Hallerstein (1780, vol. 6, pp. 292, 374-380; vol. 9, p. 440) finally proved that the Chinese were numerous and had higher fertility compared to the Europeans. For any Chinese and for their foreigners in their clear mind it was a sign that others had to learn from Chinese sources and not vice versa in the early Copernican sense, where the smaller Earth logically should circle around the bigger Sun and not vice versa. But for the aggressive Europeans it was impossible to admit their own inferiority, so they had to invent the reasons why they are still better compared to Chinese despite of being outnumbered.

The Westerners were certainly better because they used their supposed only true religion, just like the Muslims did. Therefore, the (racist) answer to the questions about the reasons for the priority in industry-technology was certainly the superiority of Christian faith. Not the Catholic church, because the Protestant church endorsed even more advanced technologies in Britain, Netherlands, or the USA, but the Western Christian faith as the way to exclude the industrially less advanced Orthodox Russians. The Western Christian answer to the question was at hand, although Chinese simply did not believe in their own inferiority before they lost the Opium Wars. The feeling of inferiority was something new to them.

The Jesuits were certain that the only way for the Chinese to avoid future defeats in wars would be their conversion to Christianity. For the Chinese authorities, 
including the Emperor, their conversion was out of question. It would be regarded as a huge defeat for China as the center of the world, somewhat like high treason against the inherited Chinese glory. The Chinese authorities could prefer the conversion of Jesuits into Confucianism, which was not completely excluded before the Chinese Rites controversy, at least in the fears of Roman authorities supported with the jealous accusation of competitive religious orders. In the long run, the Jesuits were at least partially right: the late twentiethcentury Chinese converted towards the Western scientific-technological frames modified to fit the Chinese tradition together with the import of European heresy called communism. In the long run, the Jesuits were at least partially wrong: Chinese needed no Christianity to become more papal than the Pope in the field of Westerners' economics and sciences. All they needed was the opportunity provided with Nixon's 'ping-pong' visit on February 21, 1972, after the American ping-pong team attending the championships in Japan was transferred into China from April 6 to April 17, 1971. The funny secret was that the American ping-pong team lost almost all the duels as the predecessor of Americans' lost the economic duel against the four plus times more populous China. Just like the democratic elections prepared step-by-step for the funeral of the minority German-Hungarian reign of Habsburg monarchy after 1848, the democratic economy based on the number of consumers destroyed the reign of Western Christians over the majorities of others. Democracy is the power of the numerous and the funeral of the rule of minorities no matter how wealthy they might be. The wealthy could buy or rearrange polls, but on the long term the numbers decide, just like any other kind of statistics where the numerous particles rule out leaders among them. That is why Nietzsche disliked democracy, the rule of the more numerous.

The US expert Nathan Sivin $\left({ }^{*} 1931\right)$ figured out that the Chinese performed their somewhat differently shaped industrial-scientific revolutions considerably earlier with their four great inventions of gunpowder, paper, printing, and compass. They did it in their Benjamin Elman's (*1946) own ways in the aspects hardly recognizable in Western frames. Besides the moral and religious aspect, there is also an economic-industrial answer to the apparent lack of the Chinese industrialscientific revolutions. The comparative economic research was initiated with a project of British economist-turned Dutch professor Angus Maddison (19262010) and his antagonist Kenneth Pomeranz $\left({ }^{*} 1958\right)$. American Pomeranz valued the Lower Yangzi Delta pre-eighteenth-century economy much more highly, almost as equal to its contemporary Dutch or British economies. The new research was supported with the fact that the Chinese economy proved to be 
extremely adaptable in the past decades in contrast to the previous Euro-centric view of their society as stagnant. The apparent stagnation certainly just mirrored the shock following the Chinese astonishment after they lost the Opium Wars to the enormously less numerous Western enemies, who proved to be better informed, drilled, equipped, and organized.

"The industrial revolution did not happen in China because the Chinese did not need it", was Luiten van Zanden's (*1955) Dutch answer, just like Fung's American-Chinese answer a century earlier, although in completely different economics and not the philosophical frame. In the last three centuries, the North Sea area was usually considered as the most developed part of Western Europe and the cradle of the industrial revolutions, but their alter egos in the Lower Yangzi Delta of the Hua-Lou district developed their own system of lower real wages and higher interest rates. The North Sea Basin industrial revolution was a process of inventing of thermal and mechanical tools needed to replace the expensive local labor with machines driven by coal. The Chinese production costs were (and still are) much lower and therefore they were not at all conducive to a change within a great revolution. The European entrepreneurs were very eager to develop technologies that increased labor productivity via the capital-labor ratio, while their contemporaneous Chinese businessman had much less incentive to do so (Pomeranz, 2000; van Zanden, 2011 a; 2011b; 2014, p. 62). The Chinese believed that the secret of success was in their minds, just as Fung supposed. They also believed in success of the knowhow and not in the blind, aggressive faith which bought temporary luck in war into European hands in the Americas and, to a lesser extent, all over the world. For the self-proud Chinese, the Europeans were just another barbarian tribe on their borders, like the Mongolians or the Manchu before them. The Chinese were and still are numerous and ready to absorb any kind of the intruders. The Mongolians were cruel, the Manchu were somewhat more on Han terms, but the Christian invaders were certainly the worst of them all. Not to speak of the Japanese aggressions shaped on Western terms. During the Late Qing era, the view on Europeans gradually changed as some Chinese even implicitly followed the European knowledge and technologies initially imported by the Jesuits. 


\section{Use of the knowhow and networks of European- prepared Jesuits in the Far East}

The leading Jesuits certainly needed the different profiles in different eras while their mathematical talents were always very welcome. The same goes for the Chinese authorities who learned that the technical knowhow was decisive for the prosperity of their nation and therefore admitted only Jesuits of relevant technical training to the Beijing court. Differently from the Japanese, the Chinese believed that they could borrow the Western technology without the Christian religion. The Christianity did not please all of Chinese because of its irrational dogmatism, especially the one involved with the Virgin St. Mary. The Japanese feared that there is an inseparable conglomerate between the Western technology and religion which were supposedly tightly packed together. The Japanese fear probably proved to be true during USA's rule in defeated Japan of the Second World War. The Han Chinese had a different historical memory with many advanced technologies and bearers invading China in sporadic Chinese times of troubles under the Mongol, Manchu, or whatever flag. The invaders initially behaved like enemies, but sooner or later all of them accepted the superior Chinese cultural frame. China played similar roles as the great Empires around the Bosporus called Russian, Habsburg, or Ottoman, but the Chinese state was much older and more populous. With the little help of communism, the Chinese and Russian empires did not collapse in the way the Habsburg or Ottoman empires did after the First World War. The Habsburg and Ottoman empires were a kind of fighting siblings in symbiosis between the Muslim aggression and Christian defense in the Bosporus and the Balkans. When aggression ceased to be actual with new war tools invented in Western Industrial revolutions, both partners in the symbiosis lost their raisons d'etre and collapsed to become the loot of other surviving great Western powers. To be distinguished from the Bosporus fighting dual symbiosis, the Gibraltar experienced the same dualism during the Moorish Iberian-French Septimania-Sicilian European rule from 711 until the crusaders expelled Muslims from Sicily in 1300 and Reconquista fighters conquered Granada in 1492. The trans-Gibraltar Muslim invasion ceased just at the moment when its Bosporus equivalent began after the Turkish victory which transformed Constantinople-Byzantium into Istanbul in 1453. The Russian-Chinese dichotomy developed with the Treaty of Nerchinsk (1689) supplemented with the Treaty of Kyakhta (1727), but they never reached the armed conflict symbiosis of the Habsburg or Ottoman type. In the RussianChinese negotiations, the Beijing Jesuits acted as translators. Translation is 
always also an interpretation, and Cortez' Mexican female translator probably intentionally misinterpreted several key issues, while ex-Jesuit Poirot as the interpreter on Lord Macartney's visit in Beijing probably worked with much greater integrity in 1793.

There was always a very sharp division line on the Habsburg-Ottoman border between the West and the East as well as between their predominant religions. In contrast, the Russian-Chinese border eventually developed into an osmotic one which allowed Soviet Communism to transfer to Maoist Chinese state, certainly in a somewhat transformed form to fit the Chinese peasants' needs. The real Chinese-Russian symbiosis ceased later and the collapse of the Soviet Union in 1991-1992 was not a threat to Beijing, despite similar Communist doctrines on both sides of the Chinese-Soviet border. Moscow lost its prestige for a while before Putin took the lead, but Chinese did not feel the Soviet Union's collapse as a threat to China's prosperity. The unlucky Soviet Union did no harm to the Chinese.

The Russians, and the traditional beards, suffered under their cruel masculine modernization of Peter the Great. The Westerners were near, Peter visited them, and the Russian backwardness was more than evident. Pomeranz stated that the far-away China was not backward at all during the early Jesuit interferences in Beijing. In any case, the Chinese backwardness or underdevelopment was not that obvious and indeed there was none of it in advanced Chinese cartography or in some aspects of physical-mathematical sciences, with the sole but important exception of calendar. The calendar was a decisive factor because all governments and especially the Chinese one supposedly acted as mediators between their people and the time arrow personifying the Sun or god. Certainly, Chinese emperors never played the gods themselves like Egyptian Pharaohs, Japanese Emperor, Roman Caesar's descendants, or some more modern eccentric Western rulers. The Chinese Confucians did not need their gods even though the Chinese Emperor claimed to be 'the son of heaven'. They proudly examined their past, while the Hamito-Semitic expression of time arrow with a clear distinction between the past, the present, and the future was limited and usually recent (Cohen, 1947, p. 126).

Unlike Peter the Great, the Chinese did not feel the urgent need to copy the Western ways. They confessed just the urgent need for calendrical reforms, as did their neighboring Koreans. Without any need to hurry, the Chinese preferred the moderate small changes. They relied on Portuguese and later also on Louis, Le Roi Soleil's academician French Catholic Jesuit sources. After the Jesuits' 
suppression, the Chinese wrongly concluded that they had learned enough to win all the Western challenges. They had their point for the moment, but the dynamic British, Dutch, or revolutionary France literati were preparing the surprising progress with no Jesuits left around to report about it to the Chinese. The rapid development of Western knowhow on the bayonets of Napoleonic armies were repeated once again a century later during the progress of quantum mechanics after the First World War. On that occasion in India in 1928-1929 Arnold Sommerfield told the young Subrahmanyan Chandrasekar (1910-1995) that the English translation of Arnold's textbook Atomic Structure and Spectral Lines (Methuen, 1923) which Chandrasekar studied with passion is not relevant anymore because of the recent developments in quantum mechanics.

In contrast with the sometimes quite polite Chinese relations towards Christianity, the Japanese banned the Catholics and allowed only the limited visits to the Dutch Dejima Island until the French armies raised by Lazare Carnot invaded the Netherlands and finally convinced the Japanese that the Dutch and their rangaku were not the almighty power they needed. Carnot was the generator of French revolutionary victories and in 1824 his older son Sadi used his ideas to describe the success of the generator of industrial revolution called the steam engine, which was presented to the Beijing court with Galileo's former friend Johannes Terrentius Schreck's (1576-1630) translation of 1627 and with Ferdinand Verbiest's (1623-1688) court presentation of a steampowered toy car in 1671-1672. The latter was the year of von Guericke's Amsterdam publication of his air pump research and electric friction machine for the demonstration of electric repulsions, which Verbiest was soon aware of. In 1669, Verbiest presented his U-shaped thermometer of Otto Guericke's type to the Emperor, and French Jesuit Johannes de Fontaney (1643-1710) presented the modernized thermometer and barometer to the Chinese court in 1687. The unnamed, probably a Chinese-based Jesuit, bound his manuscript about Boyle's air pump with Joachim Bouvet's (1656-1730) manuscript on thermometer, now kept in the Vatican library. He even invented the funny phonetic Chinese name of Boyle's design, which was not mutually adopted (Shi, 2013, pp. 207, 212-214).

The predominantly Chinese-invented vital parts of the British steam engine were described among others in Wang Chen’s (王禎, $†$ 1333) book on agronomical instruments in 1333. Macartney's mechanist-mathematician James Dinwiddie (1746-1815) pioneered in ballooning in London in 1783, and a decade later presented his paper on science in Beijing without discussing Watt's engine. 
Macartney brought a model of steam engine with him to Beijing, but the procedure's complications prevented the fair exchange. Dinwiddie did not return home at once but lectured on mathematics in India and became very wealthy before he dropped his anchor in England again. With no Jesuits to help, the first Chinese who properly understood the working of a steam engine in the steamboat after his work in East Asia was Ding Gongchen (1800 Fujian Province-1875) in Guangzhou in his book Yanpao tushuo in 1841. He added jiyao to that title in the later revised edition. In 1847, he published a supplementary work with illustrations. In 1851, he took a post at the Bureau of Firearms in Guilin (桂林), where he copied his book and distributed it to the military garrisons as a reference source for artillerymen. In the meantime, the Europeans built several enterprises for producing steamboats on Chinese soil with Chinese workers participating. The first working Chinese steamboat was built just after the Opium Wars and the bloody Tai-ping Rebellion (1851-1865) in April 1865 (Wang, 2010, pp. 35-36, 44, 50; Penny, 1996, pp. 3-4). The Chinese use of electromagnetism was even more postponed. The electromagnetic tools were introduced in a larger scale after the First Opium War. The war began almost simultaneously with the development of early cathode ray tubes in Bonn, which soon enabled inventing the useful Thomas Alva Edison's bulbs. The Chinese observed Aurora Borealis, used compasses, endorsed metal roofing as lighting rods, but did not show much enthusiasm for the Leyden Jar of Japanese Erekiteru or medicine, missed the Jesuits to tell them about Galvani and Volta's electricity and developed electro-acupuncture only in about 1934.

\section{The Chinese against indivisible, unstructured atoms}

In that context, it is reasonable to expect that most Chinese contributions to physics were accomplished before European Renaissance in technology. They focused on mechanics, less on heat, and very little on the Mohists' optics despite of the Chinese invention of candle and the development of oil lightning. The early Qing Chinese contributions to electromagnetism were even smaller, despite their earlier invention of the compass and knowledge of its repulsions. Although the amber from Upper Burma was very common in China, rubbing it to produce static electricity was less common compared with European Guericke's merits in the 17 th century. In the early 1880 s, the telegraph, telephone, and incandescent lighting were introduced in Shanghai and other towns, where only Morse's telegraph faced a considerable delay. The Chinese witnessed their own sort of 
US war of currents when the mayor of Shanghai, under the pressure of local domestic oil-lighting companies, forbade Chinese to use the electricity provided for the foreigners by British companies in the person of a manager named Robert William Little, who served as the chairman of the Shanghai municipal council from 16 January 1879 to 30 January 1882. Little was not so little at all and he soon persuaded Beijing authorities to press for the lifting of Shanghai mayor's peculiar ban in 1882 .

Chinese contributions to the history of physics were always great, but they were mostly written as part of broader histories before modern era. The Chinese researched predominantly during the growth of paradigms or in their ancient pre-paradigmatic states, but also very often in the revolutionary period which emerged from their mixing of Eastern and Western ideas. Early Kanada's (कणाद, Kashyapa, Uluka, Kananda, Kanabhuk) Vaisheshika-Vaiśeșika (वैशेषकि) orthodox Vedic-Hindu, as well as their competitive Buddhist merits in atomic (paramānu) concepts, influenced both Democritus' Europe and even the Mo Zi's (470/468391/376 BC) Mohists during the period of the Warring States (481/475-221 BC). The Chinese Mohist canon Mo Jing (墨經, compiled in 450-250 BC) is a sort of uncompleted Euclid with mechanics of (Boškovićs) indivisible points and optics. Later, Liu An (179-122 BC), the King of Huai-Nan during the Western Han, discussed multiple reflections. Another of the six orthodox Vedic-Hindu schools (astika) was Nyaya (न्याय, ny-äyá), whose different atomism was promulgated in the 2nd century by Akșapāda Gautama. The ancient non-Vedic non-violent religion of Indian Jainism with the swastika symbol also preached atomism and greatly influenced Mahatma Gandhi (1869-1948). The penetration of second wave Buddhist South-Indian Brahman logical Boškovićian point-like duration-less energetic atoms of Dharmakirti ( $f$. 7th century) and Dignāga (c. 480-c. $540 \mathrm{CE}$ ) gave the Chinese a new portion of short-lived southern atomism, which mostly survived in remote Tibetan Buddhists headquarters, as well as in Japan. As late as during the USA Solid State delegation visit in September 1974, the Chinese refused to study much of atomism (Bardeen \& American Solid State Physics Delegation, 1976, pp. 75, 95). Just a few Arabic alchemists endorsed atoms, while the Chinese alchemy was a distinct art already in 1100 BC. The Chinese used no acids and alkalis, but just fire for their transformation which could be considered as related to phlogiston a few centuries before Stahl. They had a remote knowledge about two distinctive substances contained in the air with supposed oxygen used for breathing and oxidations, centuries before Lavoisier and Priestley (Adolph, 1922, pp. 442-444). It seems obvious that atomism was an ideology of the warring city states and not of the unified Chinese State. Probably the unified Europeans under 
Rome, Napoleon, Hitler, or modern European Union also had some aversion towards particles and preferred waves in Peripatetic or Fresnel's ether, Heisenberg's matrix mechanics, or modern string theory views. De facto united federal USA or parts of the Soviet Union transformed into Putin's Russia are somewhere inbetween, while Leibniz and Schrödinger-De Broglie's entrance of wave theory into quantum mechanics was an echo of Chinese holistic wave influences inspired by the efforts of OUN and the unification of Europeans, which proved to be abortive for Grexit's and Brexit's particle atomism. The Pope was right in his fears in the early 18th century during the Chinese Rites controversy: the adoption of Chinese Confucianism fought back into European thought to create a doubt in three hundred years of rule of Gassendi's revival of Democritus' atoms. Twentiethcentury Europeans designed the tools to "see" the atoms which they wanted to see despite Ernst Mach's doubts, but after Mao's seizure of power even the Europeans had to admit that the atoms are divisible and therefore not atoms at all any more, even if chemistry needs atoms to fill Mendeleev's table and to describe the reactions. Leaders of the Cavendish Laboratory, J. J. Thomson and Rutherford, only started the atom-cutting story, but the seemingly endless row of particles or resonances discovered after the Second World War with the tools developed in the Manhattan Project gave the points to the Chinese wave holism as the next wave after centuries of atomic domination.

In September 1860, in Karlsruhe, Stanislao Canizzaro (1826-1920), the organic chemist August Kekulé (1829-1896), Lothar Mayer (1839-1895), and other chemists without overall agreements discussed Avogadro-Canizzaro's atomic weights. In 1869, Mendeleev and L. Mayer published their periodic tables.

Just a few years later, in 1874 and 1891, George Johnstone Stoney (18261911) proposed the divisibility of atom with the electron hypothesis which J. J. Thomson proved with his "discovery" of electron in Cavendish in 1897. The indivisible atoms were indeed extremely short-lived, although they were still discussed as facts in lower-lever schools in the 20th century. In the late 19th century, two different, almost independently developed concepts of atoms of chemists and physicists accomplished a kind of symbiosis. One was developed from Mendeleev's success and the other was an output of kinetic theory which viewed atoms as part of statistics without bothering about their chemical structure. While the indivisible atoms almost immediately became contradictious in physics, they still retain some value in chemistry which should be considered seriously in the attempt to change the name of atom. As the ill-famed "Memory of Water" brought severe criticism from the older generations of chemists, the 
angry defenders of atom's name should be expected from the generations which grew with it, including myself.

The clever Chinese were silent and did not admit having won their (secret) anti-atomic competitions until well into the 21 st century when they once again became a world power after the fiasco of Lord Macartney's embassy. The mathematical ether discussions or models of the 19th century by Cauchy and others seems to be just nice brain training after Einstein's neglect of ether in 1905. The same destiny will probably face the deep Stefan-Boltzmann's atomic mechanics research after the twenty-first-century Chinese disability to accept

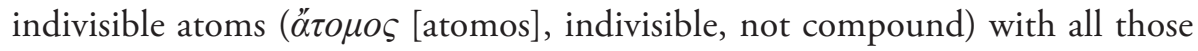
point-like quarks and strings as their constituents, although the modern string theory also likes indivisible ultimate parts with brane of dimension zero (Greene, 2004, pp. 556-569). The modern divisible 'atom' certainly is contradictio in adjecto. The reason why we still use the term 'atom' is the fact that almost nobody masters Ancient Greek any more, and therefore seldom anybody notices that the phrases like 'divisible atom' or 'the constituents of atom' are a nonsense. Soon after some ambitious Chinese fellow will translate the modern atomism into ancient Greek to prove the irrationality of the concept, the indivisible un-compound atoms will follow their old antagonist luminiferous ether into a collection of funny stories about the history of science. The development will show that Stefan-Boltzmann's atomistic discussions were not in vain, as Boltzmann feared, similarly to Cauchy's, Stokes', Fresnel's, and many other models of ether were the useful stages in the development of physics.

The Central European physicist Josef Stefan and his student Ludwig Boltzmann enthroned the atoms into physics of kinetic-statistic theory so effectively that Ernst Mach was almost the unique Habsburg first-rate physicist who dared to oppose them. Einstein's first wife was a high-school student of Stefan's student Ivan Benigar, Einstein himself was Boltzmann's fan (Einstein, 1915, p. 260), and he lectured in Mach's former chair at the Prague University. Central European atomic traditions seem to be decisive, although the ones in Britain, Paris, Berlin, or India should be also considered. If there is any logic in the world (which some doubt), the initiative for changing the mess of atomic beliefs of StefanBoltzmann's heritage could originate in the Central European milieu. Other networks expected to help are the Chinese Confucian atom doubters.

The Ancient Chinese non-Mohist non-atomistic holistic Confucian worldview endorsed more waves in mutual interactions than the discrete particles. It could finally defeat the outnumbered European atom believers. The China-based 
Jesuits invented the Chinese word 'Lord of the Heaven' for their purposes but did not bother much to introduce atomism in China because it was unpopular in the Catholic Europe of the 17th century. The French China-based Jesuits might have introduced some Cartesian atomic aspects in the modernized version of Honorat Fabri, or Parisian Noël Regnault (1683-1762) from the Collège Louisle-Grand, and connected them to the Mohist traditions, just like the Jesuits introduced the concept of the Lord of the Heaven in China. The atomism of the Jesuit Bošković was not straightforwardly introduced to the Chinese because the suppression followed too soon after Boškovićs physics was accepted in Central European milieu despite of the fact that Hallerstein used Bošković's comet theory in Beijing. The Stefan-Boltzmann atomism prevailing today was a modernization of Boškovićs atomism in Boltzmann's explanation, and previous acquaintance with Bošković could have helped modern Chinese atomists.

Yung Wing (1828-1912) was the first Chinese to get the Bachelor of Arts degree in Yale in 1854. Later he organized the abortive Chinese Educational Mission to bring more Chinese into the US educational system in 1872 and 1875, at the time when Stefan and Boltzmann published their early masterpieces. The nice Yung Wing's project abruptly ended with the Chinese being recalled in 1881 . One of the lucky graduate students was Jeme Tien Yow (詹天佑) who became the father of Chinese railroads. Many other students were recalled before they could finish their studies, but they evidently returned to China with some knowledge of Stefan-Boltzmann's kinetic atomism, even though Boltzmann paid his first visit to USA somewhat later. When Josef Stefan began his victorious march from kinetic atoms into statistical mechanics, the Chinese audience found some of the Western technical influences quite acceptable, although the Chinese probably had no Japanese Sumitomo to buy the old Western books and Chinese did not trust atoms at all. Stefan's success in Central Europe had no immediate echo from the Far-Eastern Chinese because the latter still disfavoured the atomic traditions. The Japanese had no problems with atoms in their Buddhist traditions, while Koreans were mostly on the Chinese side, although in the periods of Chinese crisis they tried to develop their independent scientific pursuits.

Stefan was enough self-assured to dismiss the ancient primary proof of atomism, which he called 'the apparent adhesion'. Stefan researched a temporary apparent viscous adhesion between two flat plates in close contact, well known to every schoolboy already in Jesuits' schools. Contrary to the older atomist who used the effect to support the apparent molecular forces which supposedly inclined plates to one another, Stefan experimentally proved that the attraction now 
named after him is a different effect of the surrounding media which needs some diffusion time to fill the vacuum created when the plates are tried to be separated. The surrounding media pours between the plates slowly at first, and later gains more speed. Stefan's law governs the flow of polymer between the solid parallel plates. The real adhesion on small distances should also appear, but Stefan's viscous adhesion is much more effective in cases used widely by tree frogs, snakes, or plants which trap insects. It could resist strong forces for a while, but a small force surpasses it after a sufficiently long time of acting. In polymers-pushing-polymers partitioning into nanoscale cavities model, the forced partitioning cells of Stefan's apparent viscous adhesion is a useful tool for molecule-selective transport and active osmotically regulated packaging. The relatively less-penetrating polymers push the more easily penetrating ones into channels of nanometer size in excess of their bath concentration in the modern diffusion model which was a descendant of Stefan's earlier ideas (Stefan, 1874, p. 316; Dennyv, 2015, pp. 310-313; Aksoyoglu et al., 2016). The diffusion and osmotic pressure itself were certainly also in Chinese frames of thought although the kinetic atoms were not welcome among the Chinese, as was not the Japanese invasion on Taiwan in 1874, which evidently tried to particulate the Chinese state into particles atoms. In those times, most of the modern educated Chinese matriculated in Japan, but many left after Japanese hostile aggressions against China.

Two Chinese trained at the Tokyo Imperial University, the Buddhist Chongqing Xu (許崇清, 1888-1969) and Fangbai Li (1890-1959), first introduced the special theory of relativity for Chinese in 1917. Chongqing Xu believed that Buddhism should be mixed with modern science, while Fangbai Li relied mostly on US sources. Three decades after Stefan's work on apparent adhesion, in 1903, Yan-Fu (嚴復, courtesy name Ji dao, 1854-1921) introduced the word Mo-Po as something indivisible like atom into Chinese vocabulary in his translation of John Stuart Mill's Logical System. Two millennia of unified China seemingly collapsed eight years later with the downfall of the last Chinese imperial dynasty. Except for Taiwan and until recently Hong Kong, China remained one, but the Chinese had to accept the European atomistic thought at least in principle. Inbetween the chief protagonist of atoms, Boltzmann hanged himself, proving not to be just another number in someone's statistics.

The Chinese atomism penetrated with their domestic experts trained in Germany and the USA, but also in Scotland. In 1907, Li Fuji (Li Fo Ki, 李复幾, 1885-1947) from Shanghai was the first Chinese to obtain his PhD in Western 
Universities. He studied P. Lenard's theory of spectra of alkali with Henrich Kayser in Berlin. In 1907, Yuanli Hsia (夏元瑮, 1883-1944) graduated from Yale with the opponent of the theory of relativity Henry Bumstead (1870-1920) and studied with Planck and Heinrich Rubens in Berlin until 1912. Under Bumstead's influence, Yuanli Hsia accepted Einstein's relativity only after his studies with Einstein in Berlin in 1919-1921.

In 1909, Tatsung Chang (张大椿, 1883-1978) graduated in electrical engineering from Yale and assumed a prestigious chair of physics in Beijing. During his time, Yale already offered the curriculum in physics, but some Chinese probably felt that more engineering education should be brought back to their troubled fatherland. In 1915, Li Yaobang (1884-1944) won the second Chinese overseas $\mathrm{PhD}$ in physics after his studies with Millikan at the University of Chicago with a Christian stipend for the Determination of the Value of "e" by Millikan's Method, Using Solid Spheres in 1903. In 1910, Li Yaobang was followed by Yan Renguang (Kia-Lok Yen, 颜任光, 1888-1968) who also worked on Millikan's oil-drop experiments but got his $\mathrm{PhD}$ on Leibniz's logics in 1918. After his 1924/1925 year spent with Rutherford in Cavendish, KiaLok Yen established the first Chinese factory for the manufacturing of Westerntype scientific instruments. In 1927, Zhao Zhongyao (Chung-Yao Chao, 趙忠 堯, 1902-1998) came to Millikan after his inadequate Chinese studies of the scattering off gamma rays at Quinghua University. The first Chines Quantum mechanics expert Shou-Chin Wang (王守竞, 1905-1984) got his PhD at Columbia University in 1927 . The expert in general relativity Pei-Yuan Chou (周培源, 1902-1993) received his $\mathrm{PhD}$ a day after him at California Institute of Technology (CalTech). Wang later conducted research with John H. Van Vleck in USA, as did Thomas Kuhn after him. Wang became the father of Chinese heavy industry, while Chou accomplished his postdoc with Heisenberg and Pauli in Germany. Among the first eight Chinese female physicists were Ming-Chen Wang (王明贞, 1906-2010), the younger sister of S. C. Wang, and ChengShu Wang Chang (王承书, married Chang (Zhang 张), 1912-1994). They graduated from the Yenching University and the Yanjing University, respectively, the latter of which was dissolved in 1952. Ming-Chen Wang and Cheng-Shu Wang Chang studied with George Uhlenbeck in Michigan before becoming his collaborators to accomplish significant contributions to statistical physics and Brownian motion of atoms in 1945 (Hu, 2016). From 1968 to 1973, ChengShu Wang Chang was sadly imprisoned during the Cultural Revolution while her brother worked in the MIT Lincoln laboratory in the US after his excellent publications on atomistic quantum mechanics in the 1920s. At least the brother 
and sister Wang had no more Confucian problems with atoms (Wang, 1928; Wang \& Uhlenbeck, 1945).

In the meantime, while having the first physicists educated in Western countries, the Chinese produced some valuable translations. In 1897-1898 in Shanghai, the Presbyterian minister Watson MacMillan Hayes (1857-1944) published a part of the translation of Adolphe Ganot's (1804-1887) book of experimental instruments, supplemented with John Tyndall lectures, in the 14th English edition. A quarter of a century earlier, Nikola Tesla used the German translation of Tyndall's Heat Considered as a Mode of Motion (1865) already during his studies in Rakovac. In 1897, Heyes also published in Shanghai his translation of Elias Loomis' (1811-1889) Astronomy to supplement the efforts of Li Shan Lan (Tenshu, Qiuren, 1810-1882) and the preacher Alexander Wylie (1815-1887), who published their translation of Loomis' calculus in Shanghai in 1859, as well as the translation of John Fredrick William Hershel's (1792-1871) Astronomy in 1875 .

The Japanese connections were also vital. The Japanese did not hesitate to provide their translation of the European entropy research, although nobody outside German-English linguistics networks, except Russians, bothered to translate Clausius' or Boltzmann's original fundamental researches on entropy. The Far-Easterners preferred the compilations, except for Maxwell or Tyndall's very popular contributions. The 1903 Tokyo Imperial University graduate and the Yerkes Chicago University postgraduate of 1905-1907, Ichinohe Naozō (1872-1920) of the Tokyo Observatory (1908-1911) published his Japanese translation of Maxwell's elementary popular text without the mathematical aspects of statistical interpretation of entropy Matter and Motion (1877) in Tokyo in 1917.

Two graduates from the Tokyo Imperial University began the quantization among the Chinese. Xu Chongqing (1888-1969) was the first to use term liangzilun ('quantum theory') in Chinese literature in 1917, and Zhou Changshou (18881950) introduced the scientific concepts of the old quantum theory. The modern Copenhagen quantum theory was given the Chinese names liangzi lixue, or yuanliang lixue, while the wave mechanics became bodong lixue or ox bo lixue. Certainly, the early Chinese students were 'learners' rather than 'knowledge circulators' of Western knowhow.

Besides studies abroad and translations, also domestic Chinese schools Westernized. The best Chinese universities with Westerners as heads were in 
Shanghai, while in the Yenching University an American founded a Christian mission college in Beijing, where the graduate of the Liverpool University William Band (1906-1993) taught physics from 1929 to 1941. At first, Band did not have many students, but some female students also enrolled. In 19301931, before the Japanese invasion of Manchuria on September 18, 1931, Band was among the first to teach thermodynamics and quantum mechanics with the statistical theory of heat and chemical applications in Beijing as a valuable descendant of Jesuits a century and a half before. In 1933, mere 43 per cent of Chinese universities covered quantum mechanics in their curricula. Band also taught Natural Philosophy of Modern Physics, Radio-Telegraphy and Telephony on his locally built station. With his students, Band published a number of research papers before he was forced to leave under Japanese threats in 1941 (Hu, 2014, p. 256).

Many Chinese still relied on the Eastern origin of Western sciences with the great four Chinese inventions, such as Tang Caichang (1867-1900) in his discussion of Daoist alchemy of Zhu Xi (1130-1200), published posthumously in 1903. In 1920 and later, Wing Jin (1888-1966) praised the old Chinese chemistry and mathematics, but not physics without the concept of atom in his articles published in Kexue. In 1920 and 1923, the US educated Zhang Zigao ( 張子 高, 1886-1976) published the first Chinese monograph on history of science, stating that the Chinese did not theoretically develop their inventions of compass and gunpowder and they developed no physical science (Amelung, 2014, pp. 49-50). It seems that the Chinese jumped over the earlier kinetic atomistic and statistical mechanical concepts. They transformed from the Jesuits' Newtonian classical mechanics directly into relativity and quantum mechanics without the intermediate European nineteenth-century steps of Josef Stefan and his student Boltzmann.

People in the Far-East suffered no obstacles of Christian, Judaist, or Islamic monotheist creationists anthropocentric religions against statistical physics. But the Chinese atomism was lacking. They never pioneered in anything like Japanese Buddhist atomism, Japanese Christian converts' research, Nagaoka's Saturnian model, or Nishina Yoshio's (1890-1951) atomic physics with Japanese nuclear projects. As a youngster, Nagaoka convinced himself that Chinese classical Zhuangzi yin-yang model was quite fit for description of lighting with positive-negative electricity, or as an explanation of Stefan-Rayleigh's blue color of the sky (Ito, 2016, pp. 19, 197, 198). In spite of hidden obstacles to atomism, the modern Chinese computational nanoscale transport theory widely relies 
on Lao-Tse's teachings of the endless divisibility of rods (Zhu \& Liu, 2016, p. 13). Pei-Lin You of the Institute of Quantum Electronics at the Guangdong Ocean University, as a leading researcher of electric dipolar properties of atoms and especially the hydrogen atom, proved the supposed polarity of atoms in Rutherford's (1911) model during a decade of intensive experimental research (You, 2010). It seems that at least some Chinese still study modern physics without firmly believing in atoms which reminds them of the warring states period and the unwanted risky division of the Chinese state.

\section{The Chinese scientific-industrial revolution(s)}

Chinese industrial traditions probably lost their duel with European competitors during the space of time which began with the suppression of Jesuits (1773) or with the death of the last competent China-based ex-Jesuits. Amiot wrote to Macartney about the Chinese world being upside down, but he died on October 9, 1793, soon after Macartney's arrival on 21 August. Cipolla passed away in 1805, and Poirot in 1813. The Chinese post-Jesuit stagnation ended with their painful awakening during the First Opium War, which began in 1839. Nothing seemed to be the same afterwards. The interval between the end of the Jesuit mission in China and the Opium War places the time of Chinese defeat in their competition against Europeans somewhere to the period of post-Napoleonic expansions of British industrial facilities to the European mainland. During the expansion, the victorious British (and less victorious Americans) learned all they needed for the massive production of equal parts of machines with the use of newly-invented metallic machine tools, which were first introduced in massive ball-canon production of the French revolutionary wars. The final output of noisy, bad-smelling steam engines production facilities probably looked like an alien world to the newcomers in Europe, and even more in the Westernized Far East. The astonished Chinese simply did not understand what kind of fire was propelling the steam-engines in the same manner as native Americans would not understand the combination between the rider and conquistador's horse, or the natives failed the understand the modern planes which Osama bin Laden's followers launched in their attack on New York's twin towers on September 11, 2001. Like the Native Americans who became superior riders, the Chinese developed into superior industrialists, although the Native Americans were quicker because the Chinese needed almost a quarter of a century after their defeat in the First Opium War to build their first domestic steam engine. 
The Chinese were simply unable to recognize and connect their own domestic industrial tradition with the monster that the Europeans had created from it. The lack of linguistic and descriptive geometry capacities deprived the Chinese of the possibilities to perform their industrial espionage quicker. They had troubles with hiring the European quislings to pass the secrets of knowhow, just like Venetians on the island of Murano who managed to copy some Chinese porcelains and hid their secret glass and mirror production for a while, until the Parisian minister Jean-Baptiste Colbert secretly resettled some Murano experts for the Louis, Le Roi Soleil's enterprises in Versailles in 1665. The Spaniards also kept Barba's amalgamation process secret until ex-Jesuit Ignaz von Born's intervention and the great Spanish order of mercury from Idrija Mine in the late 18th century. The Chinese industrial tragedy continued and it took the otherwise smart Chinese almost two centuries to become again the leading industrialists worldwide. With a few Jesuit double spies in Beijing in the 1820s, Chinese warship steamers may have arrived in London and not vice versa.

The China-based Jesuits introduced some machine tools for shaping metal for clocks, but the quite different Chinese technical tradition preferred wood, which however was not good enough for a mass production of metallic steam engines' parts. The industrial production of pieces of machinery of exactly the same dimension with tolerances about $1 \mathrm{~mm}$ was needed, as well as the understanding of the process, which postponed China's domestic production of steam engines for a whole generation during a conflict between two different traditions of industrial productions, which usually happens on such occasions. During the Napoleonic Wars Europeans learned to produce cannons and cannon balls with the needed precision to enable the growth of the military industry as well as the industrial killings symbolized by the revolutionary guillotine. The inherited Bohemian artillery practice was no longer needed with industrialization of their deadly work. The crucial Chinese handicap might have been their lack of any relevant training in Gaspar Monge's descriptive geometry, which forced the Chinese to build the wooden models of machines instead of drawing the projection pictures with a Monge's method, introduced in the École Politechnique in Paris. Monge's textbook was kept as a secret even in Europe, in France and there was no Jesuit to tell about it to the Beijing Emperor. Sadi Carnot got his name after the Persian poet Saadi Shirazi (1213-1291), who was the object of Parisians' admiration in those times. Despite Carnot's evident international orientation, the mutual success of Carnot and their contemporaries remained European for a while, because no more Jesuits were charged for its transfer to the East. The Japanese copied the Westerners' knowhow to play the role of Bismarck's 
Prussia, but they had no Germany to unite. Therefore, the Japanese picked up their neighboring parts of Korea and China for the Japanese expansion, but the Japanese proved to be too cruel and racist to win any kind of Prussian and Bismarck's German unification. As a reward, they got the humiliating US home rule for decades.

The Chinese did not replace their suppressed Portuguese-French Jesuit informers with anyone equal until it was too late after their defeat in the Opium Wars. Before the First World War, the defeated and humiliated Chinese (bainian chiru, 百年耻辱) had to borrow the Western knowhow from the translations from the Japanese, after the Japanese had been borrowing from the Chinese during the previous millennia. The choice of non-dangerous Portuguese Jesuit informers was clever, but the selection of dangerous Japanese non-Jesuit informers proved to be wrong, just like the Russian long-term borrowing from the French culture, which finally invited Napoleon to conquer Russia like the Swedes and Poles before him and Hitler afterwards. The lesson is obvious-it is possible and safe to borrow scientific-technological knowhow from a country too small or too distant for it to become aggressive and harmful. The Portuguese in Beijing and the Dutch in Dejima provide good peaceful examples. Both behaved much more aggressively in Portuguese Latin America or in Dutch Indonesia, but they were nice when they were confined in the strong authoritative states of China or Japan. So, if you were from the Far East, you could deal with the Westerners, but they should be chained all the time, just to limit their appetites.

It is always dangerous to borrow from the nomadic barbarian neighbors, because they will occasionally try to invade you like the Germans invaded the Roman Empire after long-term serving in their armies. In the same spirit, the Manchu invaded in China, and Attila's Huns or Mongolian hordes invaded both opposite sides of highly civilized agricultural Eurasia. As a lucky turn of events, the nomadic barbarian neighbors turned invaders usually transformed into polite ruling dynasties after a while. Barbarians have no strong feelings about their own culture or civilization and like to adopt non-nomadic ways in case their hosts are willing to cede their political power to their nomadic invaders. After some bloody battles, the nomadic intruders brought new blood into the metropolis of the former rulers.

But, one should never be so foolish to borrow from the great nations or from neighbors who used to be one's own fans. The Japanese in China in the first half of the 20th century or the Germans in France in 1870-1871 were good, and frightening, examples. And most of all, one should fear the aliens who sailed from 
nowhere into one's harbor like the Spanish-Italian Coulomb, Cortez, Pizarro, or the White Westerners in North America or Australia. They came to stay, they brought diseases, and they showed no respect to the conquered civilization. If they are just pirates like Vikings, Commodore Perry, post-nuclear bomb Americans in Japan, the Victorian British Empire in India, or the Westerners in modern Middle East oil wars, it is bad but one could hope to survive after the raiding. One could end up alive, even though poor and robbed. The nomadic pirates or robbers or blind modern businessman are bad, but you could survive their aggression, while the farmers or settlers landing in your harbors declare your end, your death by epidemical disease, swords, or the modern drones.

So, the simple question about the origin of industrial revolution needs a simple answer: Chinese didn't succeed in the Westerners' ways because their inherited ethics would never allow them to be so cruel. They were unable to torture their own folk in the industrial suburbs of Charles Dickens (1812-1870) or Karl Marx's era. Their ethics never let them be free enough to kill entire nations like the Westerners did in the Americas or Australia, while the Western aggressors at least partly failed to accomplish the complete disaster in Africa or Asia. Even the notable modern scholars still consider those areas as backward in some sense (Cohe, 1947, p. 28) without noticing that the Europeans are to blame. And last but not least, the Chinese had no priests which would promise them paradise for carrying out all kinds of atrocities like destroying the native American civilizations. The Chinese knew-if they destroy the natives to make a place for themselves, they may get wealthy, but they will never be happy. So, they preferred to stay at home before the late 20th century. And in the 21st century they quickly proved to be more papal then the Pope in their own kind of hunger for expansions worldwide.

\section{The Jesuit connection}

Did the Pope suppress his own most obedient servants, the Jesuits, to stop their double espionage in Beijing? Did he destroy the Jesuit bridge between Europe and China in order to hide the European production of knowhow which was derived to defeat the Chinese in the Opium Wars? Did Europeans feel that their industrial revolution is technically bringing them above the knowhow of the ancient empires like Chinese before Macartney's embassy and the Opium Wars? 
It is true that the Portuguese Marquise Pombal and the Spanish court initiated the suppression of Jesuits and the French joined them a little while later. But the First Opium War broke out only with the British on the European side 66 years after the suppression. The French joined the Second Opium War only fourteen years after the British won the first one. It is true that the suppression ceased the Jesuits' transfer of European knowhow to Beijing, but what role could the Protestant British have in the Pope's decision? Lord Macartney (1737-1806) smelled the war two decades after the Jesuits' suppression and acted as a spy about the Chinese knowhow, but was he able to provoke the Pope? The Irish Scotsman Macartney grew up as diplomat after the Seven Years' War which the British won a decade before the suppression of the Jesuits. Macartney was in Russian and trans-oceanic duties most of his lifetime. The British certainly disliked the Jesuits, but to plan their suppression to isolate China from the information about the advancement of European knowhow? The Europeans of those times were certainly mean and clever, but were they clever enough to plan a war which would break out 66 years later?

Almost nobody could be that smart. Hallerstein and his fellows observed the vanishing efforts of their predecessors dedicated to establishing the Jesuits' mission in China. There will be no new Jesuits and they are supposed to die in Beijing as the last of their kind! The feelings of Hallerstein, Bishop Godefridus Laimbechoven, and their few years younger French Jesuits fellows Michel Benoist or Joseph-Marie Amiot were understandably sad. They were devoted members of a corporation which flourished and grew in China for two centuries, and now everything was lost even if the friendly Lazarians could use some of their heritage.

What is the feeling when you find out that your life's work has been in vain? Certainly not very promising. What is the feeling when you find out that the life's work of all thousands of your loved ones in ten generations of your Chinesebased predecessors were burned into ashes? Certainly a disaster. When the new general of Jesuits, the former Ljubljana professor Gabrijel Gruber wrote an invitation to Chinese Jesuits to rejoin their old organization with the same oldfashioned rules, Luigi Cipolla and Luis de Poirot accepted in September 1802 and in 1805. You would not need to ask Agatha Christie's Hercule Poirot to find out how happy they were. There was hope again for the ex-Jesuits in faraway China, even though a small one. 


\section{The graphical comparison of non-European physics}

Chinese and other non-European physicists were a leading force worldwide up to the Spanish "discovery" of America. The Chinese were at least equal to the Europeans up to Macartney's embassy of 1793, but their technological and even experimental contributions much surpassed their theory from the modern European point of view. Certainly, the estimation of an European-educated author approaches all three contributions to physics in theory, experiment, and technology as reasonably balanced. With the European eyes, it is hard to judge the Chinese native theoretical physics before the Opium Wars because it had the sign of philology or philosophy with rare mathematical-logical elements included. As such, it is hard to recognize it as a physical theory in the European sense, although it surely was one of them.

Figure 1. Chinese and other non-European technology, experiments, and theory of physics

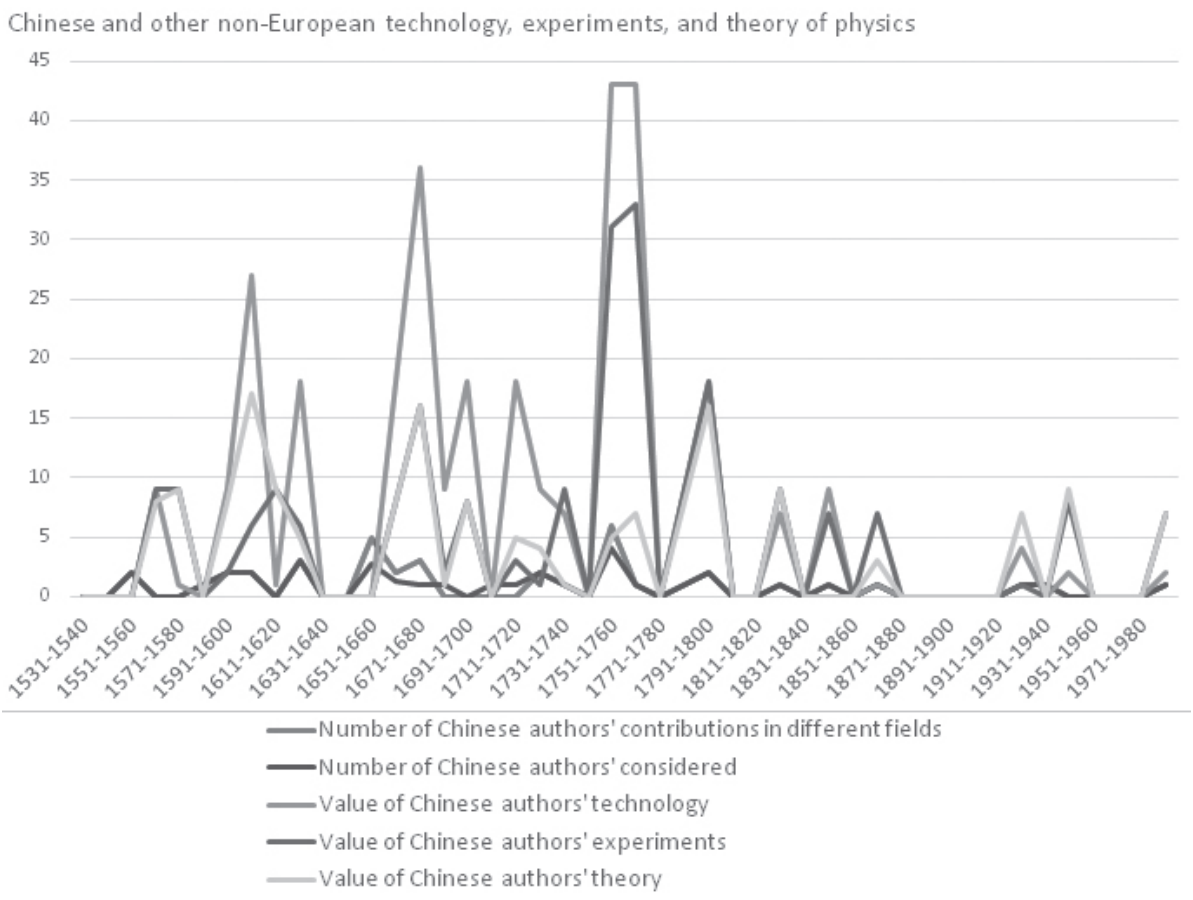




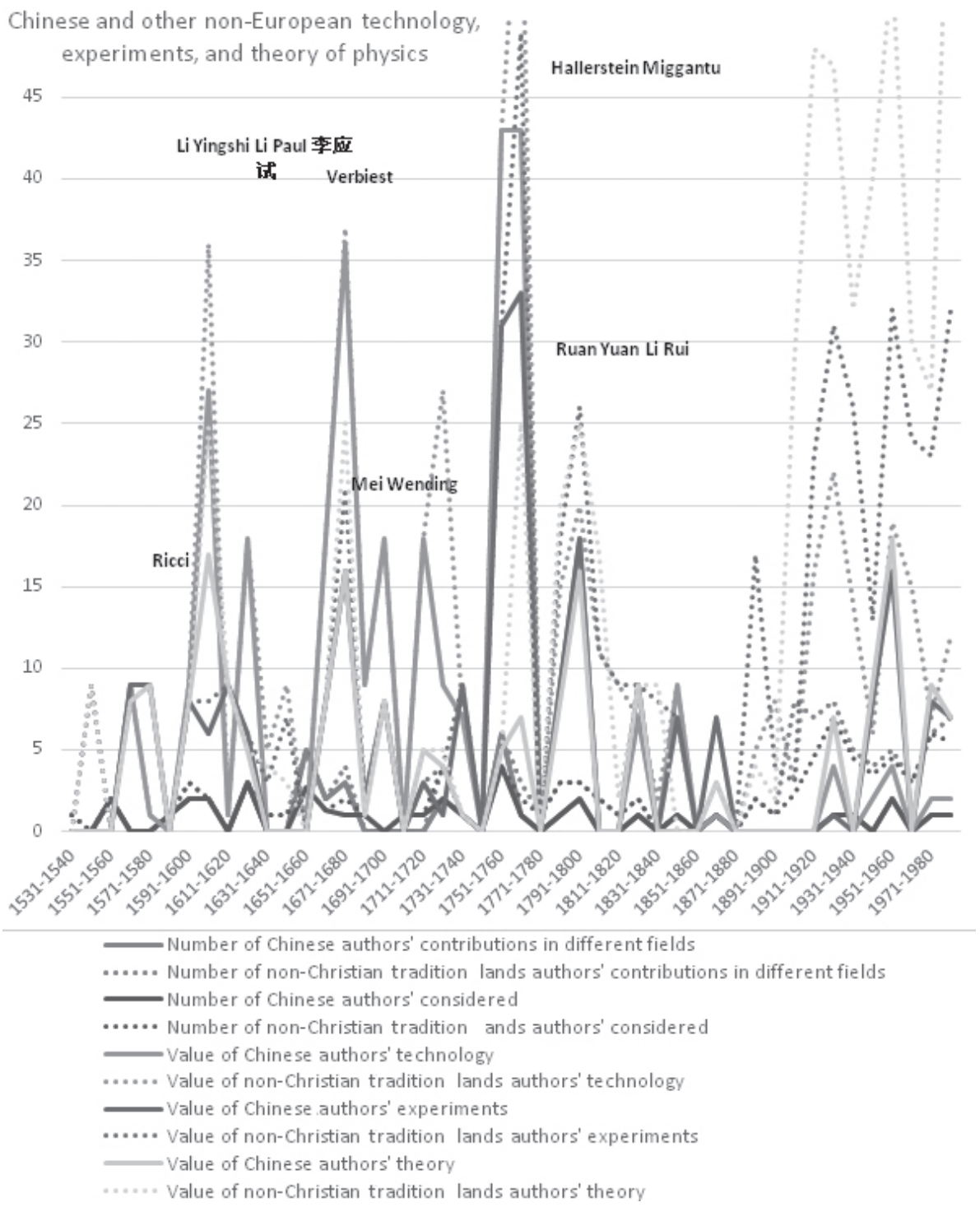

Figure 2. Chinese and other non-European technology, experiments, and theory of physics

Note: The sample contains 1,000 leading physicists' contributions in four branches (mechanics, electromagnetism, optics, theory of heat) valued from 0 to 9 according to their contributions to theory, experiments and technology. 


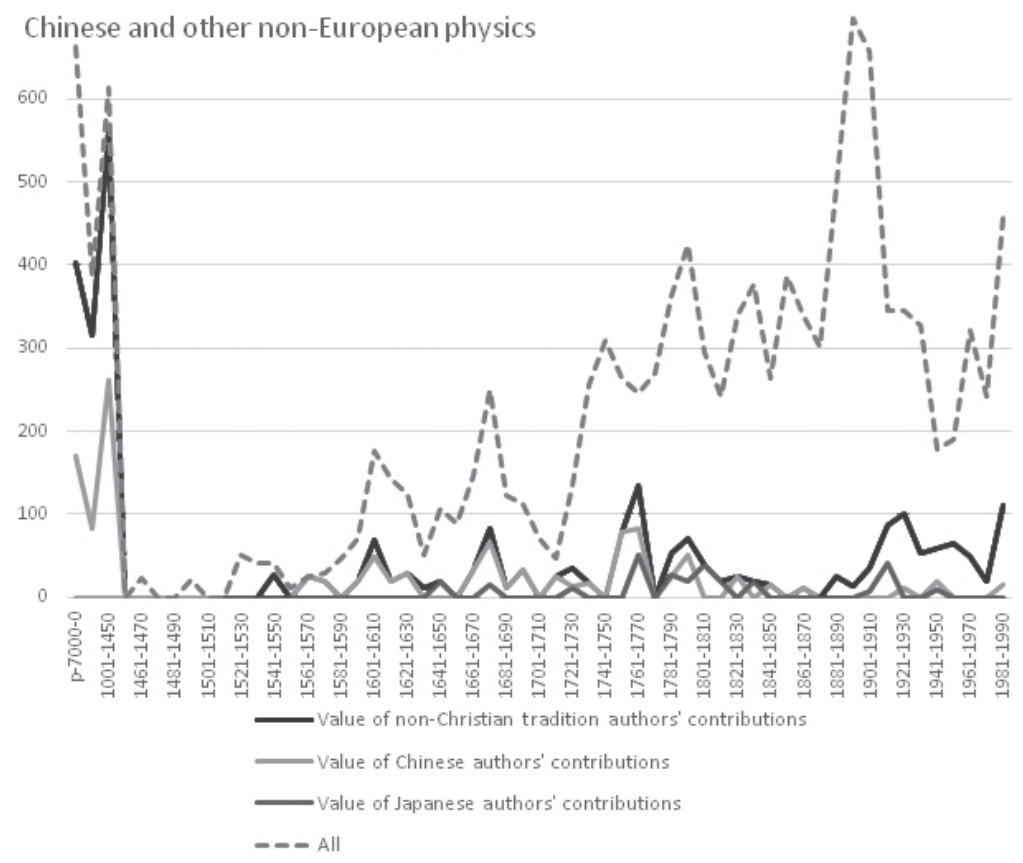

Figure 3. Chinese and other non-European physics

In the decades following the Napoleonic Wars, the Chinese made only scarce contributions to the research in physics, although their work in the history of (their) sciences was still well cultivated. After Fang's scary questions and the return of Chinese students from abroad, the situation became slightly better with Mao's Chinese nuclear program and the first Nobel Prize in Physics awarded to Chinese elementary particles theoreticians working in USA in 1957.

All non-European contributions to the (European-shaped) physics could be estimated to 25 per cent while a large part of over 10 per cent of the whole contributions belongs to the Chinese. In that estimation, we took Jewish physicists as working in non-European traditions, which is highly doubtful for Einstein or for a son of a Jewish mother Niels Bohr. In that view the physicists of Jewish descent are slightly less effective compared to the Chinese, but the Jews contributed more than Japanese while the share of Arabic is also not negligible, mostly before Galileo's turnover. In this light we regarded the China-based Jesuits as Chinese physicists even if they were born Europeans, such as Mattheo Ricci with his Chinese students Chiutaisu (Qu Taisu, 睢太素, Changshu, 1549 Suzhou-1612) and Zhang Yangmo (Ciamiamue) from the Beijing Hanlin Academy (Sasaki, 2013, pp. 37-39), Schall von Bell, Verbiest, or Hallerstein, while the Beijing scientist of Mongolian origin, 
like Hallerstein's collaborator Miggantu, were still considered Mongolian. In that way, the Japanese martyr mathematician and astronomer Saint Carlo Spinola (1564-1622) from Genova nobility, who determined the geographical distance between Macao and Nagasaki also belonged to the Japanese tradition of applied mathematics. That distinction seems to be a little unfair, but it is convenient. For a space of time before the Jesuit suppression the Chinese were the leading nonEuropean power in physics, but in the aftermath their share declined as did all the work of the local specialists of nations suppressed under imperialist boots. Under the imperialist pressure, the Japanese were the first to recover with Nagaoka and other foreign-trained experts, but their ways supported the Japanese imperialism instead, and finally provoked the sad enforced US supremacy a century after Commodore Perry's threat.

European contributions in physics were challenged again in the third millennium with the economic giant of China. Only six physicists from China have shared their Nobel Prize for Physics up to now and most of them were connected to the US, but the future physics might become predominantly Chinese. Because of their important share in mixing the different traditions, all non-European and female physicists and Nobel Prize winners were included in our network, but not all Nobel laureates of European origin were considered good enough, also because of some doubts about the honesty of modern Nobel Prize decision makers.

\section{Conclusion}

The naming of atoms needs a change and people from the Far-East are best suited to enforce it. For the Chinese and progressively also people worldwide, the advanced technique is undoubtedly in the heart of our material wellbeing. In its susceptibility, the inherited mentality plays a decisive role. In traditionally oriented societies, people sometimes tried to resist the introduction of certain technological innovations. They knew that the new inventions cannot be accepted without accompanying ideology of their inventors. The mayor of Shanghai formally forbade the Chinese from using electricity in 1882, also under the pressure of oil-lamp producers, but the Beijing government soon forced him to lift the ban. Japanese and other Easterners rightly sensed danger after their first contacts with Western Christianity. Therefore, the mobile societies of ethnically mixed settlers in the Dutch polders, on the once Native-American plateaus of USA, or in the mining areas of Idrija in Carniola, changed their way of life 
more easily while they adapted to the new challenges. The traditional habitbound country people grew accustomed to the modernized technologies with much more difficulty and much more slowly. The powerful organizations find it harder to correct their views of the world and of the management of it in comparison with the more loosely associated people or companies accustomed to nomadic networks. Therefore, the Iberian shepherds following their domestic Reconquista prosecution against Moors and Jews easily decimated the American natives without feeling excessively guilty of their own bloody crimes. They were simply told that their victims were somewhere between apes and humans. Western Protestants were later similarly cruel to their own countryman in their staged industrial revolution(s) with dirty primitive accumulation of capital. The gigantic China and its neighboring economies had advanced technology in their days, but their strong Confucian or Buddhist ethical concerns prevented them from incurring to their own confreres so much suffering. A century and a half ago the situation in British industrial suburbs was described in Dickens's novels and in Marx's theory. Compared to most other Central Europeans, the Idrija native people of miners' descent had better conditions, because the dirty work with dangerous mercury and fight for wages already became entrenched in the heart of their medieval city and did not need to be repeated.

The Japanese islanders were concerned enough with their own national security threats to obey their leaders in their visions of the Westernization of Japan. They became more papal than the Pope and dropped their third atomic bomb to Fukushima after decades of American semi-occupation. The similar Soviet Chernobyl disaster with the lost Afghanistan war and inability to sell the advances of expensive space technological inventions to their poor local domestic people provided the circumstances for the dissolution of the Soviet Union, while the Japanese state was not in great danger after the Fukushima accident.

The Westernization of China did not materialize at any profound stage because the Chinese still preferred the Easternization of Europeans and their satellites of North America and Australia. Modern physics still looks like a Western product of the early 20th century, but the Chinese and other non-European experts probably already reshaped it on their own ways. The science is now becoming a mixed field of various foreign cultures, exactly in the same fashion that the Pope feared during his Chinese Rites controversy. The changes of Catholicism are probably not among the Chinese goals because they evidently prefer the changes in physics. The numbers are certainly still on the Chinese side. Will they succeed in reshaping postmodern physics on their own ways? Will they change 
the name of ultimate chemical particles from atoms to something sounding more Confucian with the little help of Europeans? The comparisons between physics and chemistry networks in different eras and areas suggest that Chinese science without the central concept of indivisible atoms has its chance. The European term 'atom' fully reflects the conflicts of Western and Eastern views as only the Easterners could fully understand ancient Greek term 'atom' as obsolete.

\section{References}

Adolph, W. H. (1922), 'The history of chemistry in China,' Shantung Christian University, The Scientific Monthly, vol. 14, no. 5 (May), pp. 441-446.

Aksoyoglu, M. A.; Podgornik, R.; Bezrukov, S. M. \& Parsegian, V. A. (2016), 'Size-dependent forced PEG partitioning into channels: VDAC, OmpC, and $\alpha$-hemolysin,' Proceedings of the National Academy of Sciences, vol. 113, no. 2. https://doi.org/10.1073/pnas.1602716113

Amelung, I. (2014), 'Historiography of science and technology in China, bridging East and West through physics,' in J. Tsu \& B. A. Elman (eds.) Science and Technology in Modern China, 1880s-1940s, vol. 27, Beijing: Brill, pp. 39-65. https://doi.org/10.1163/9789004268784_004

Bardeen, J. \& American Solid State Physics Delegation (1976), Solid State Physics in the People's Republic of China: A Trip Report of the American Solid State Physics Delegation, Washington, DC: The National Academies Press. https://doi.org/10.17226/19966

Bolt, J.; Timmer, M. \& van Zanden, J. L. (2014), 'GDP per capita since 1820,' in M. Moatsos, J. Baten, P. Foldvari, B. van Leeuwen \& J. L. van Zanden (eds.) How Was Life?: Global Well-Being Since 1820, Paris: OECD, pp. 57-72. https://doi.org/10.1787/9789264214262-7-en

Castelvecchi, D. (2016), 'Majority of mathematicians hail from just 24 scientific 'families'. Evolution of mathematics traced using unusually comprehensive genealogy database,' Nature News, vol. 2/5.

Cohen, M. (1947), Le Langage: Structure et Evolution. English translation 1970: Language: Its Structure and Evolution, London: Souvenir Press.

Dennyv, M. (2015), Ecological Mechanics: Principles of Life's Physical Interactions, Princeton: University Press.

Einstein, A. (1908), 'Elementare Theorie der Brownschen Bewegung,' Zeitschift für Elektrochemie, vol. 14, no. 17, pp. 235-239.

https://doi.org/10.1002/bbpc.19080141703 
Einstein, A. (1911), 'Eine Beziehung zwischen dem elastischen Verhalten und der spezifischen Wärme bei festen Körpern mit einatomigen Molekül,' Annaler der Physik, vol. 339, pp. 170-174. https://doi.org/10.1002/andp.19113390110

Einstein, A. (1915), 'Theoretische Atomistik,' in E. Lecher (ed.) Die Physik. Die Kultur der Gegenwart, Part 3, sec. 1, vol. 1, Leipzig: BG Teubner, pp. 251-263.

Einstein, A. \& de Haas, W. J. (1915), 'Experimentellen Nachweis der Ampèreschen Molekularströme,' Verhandl. Dtsch. Phys. Ges., vol. 17, pp. 152-170.

Fichte, J. G. (1974), Osnova cjelokupne nauke o znanosti, Zagreb: Naprijed. [Original: Fichte, J. G. (1794), Grundlage der gesamten Wissenschaftslehre, Leipzig: Gabler.]

Fung, Y. L. (1922), 'Why China has no science. An interpretation of the history and consequences of Chinese philosophy,' Intern. jour. of ethics, vol. 32, pp. 237-253. https://doi.org/10.1086/intejethi.32.3.2377487

Fung, Y. L. (2016), Kratka zgodovina kitajske filozofije, transl. by Peter Amalietti. Ljubljana: Amalietti \& Amalietti. [Original: Fung, Y. L. (1934), A Short History of Chinese Philosophy, New York: The Macmillan Company.]

Gargiulo, F.; Caen, A.; Lambiotte, R. \& Carletti, T. (2016), 'The classical origin of modern mathematics,' JPR Data Science, vol. 5, no. 26. https://doi.org/10.1140/epjds/s13688-016-0088-y

Gearhart, C. A. (1905), 'Einstein before 1905,' Am.J.Phys., vol. 38, no. 5, pp. 468-480.

Greene, B. (2006), Tkanina vesolja, Tržič: Učila. [Original: Greene, B. (2004), The Fabric of the Cosmos, New York: Random House.]

Hallerstein, A. (1780), 'Dénombrement Des Habitants de la Chine, traduit du chinois, par le seu. P. Allerstain, Président du Tribunal des Mathématiques,' Mémoires concernant l'histoire, les sciences, les arts, les moeurs, les usages \&o. des Chinois: par les missionnaires de Pe-kin, vols. 6 \& 9, Paris: Nyon.

Hu, D. (2014), 'Bridging East and West through Physics,' in J. Tsu \& B. A. Elman (eds.) Science and Technology in Modern China, 1880s-1940s, vol. 27, Beijing: Brill, pp. 245-268. https://doi.org/10.1163/9789004268784_011

Hu, D. (2016), 'American influence on Chinese physics study in the early twentieth century,' Physics in Perspective, vol. 7, no. 4, pp. 268-297. https://doi.org/10.1007/s00016-015-0174-8

Ito, K. (2016), 'Research in pre-war Japanese physics,' in D. G. Wittner \& P. C. Brown (eds.) Science, Technology, and Medicine in the Modern Japanese Empire, Abingdon: Routledge.

Jones, R. (2009), 'The Human Genome, American Societies, The Clinical Epidemiology of Pathological Antisocial Thinking, and Albert Einstein,' Paper presented at the annual meeting of the Association for the Study of African American Life and History, 12 Feb 2009, Atlanta Hilton, Charlotte, NC.

Kim, Y. S. (2004), 'The "why not" question of Chinese science: the scientific revolution and traditional Chinese science,' EASTM, vol. 22, pp. 96-112. 
Leibniz, G. W. (1715), Discours sur la théologie naturelle des Chinois (Lettre sur la philosophie chinoise à $M$. de Rémond), Paris.

Penny, J. (1996), 'Ballooning in the Bristol region, 1784 to 1786,' The Opening Chapter in the History of Local Manned Flight, Fishponds Local History Society. Retrieved from fishponds.org.uk/balloon.pdf [accessed 17 Aug 2016]

Perrin, J. B. (1909), 'Mouvement brownien et réalité moléculaire'’ Ann Chim. Phys., vol. 8 , no. 18 , pp. 5-114.

Pomeranz, K. (2000), The Great Divergence: China, Europe, and the Making of the Modern World Economy, Princeton: University Press.

Saje, M., ed. (2014), A. Hallerstein - Liu Songling 刘松龄-The Multicultural Legacy of Jesuit Wisdom and Piety at the Qing Dynasty Court, Maribor: Kibla/Ljubljana: ARS.

Sasaki, C. (2013), Descartes's Mathematical Thought, Dordrecht: Springer Science \& Business Media.

Shi, Y. (2013), 'The new thermometer and a slice of experimental philosophy in the early Quing court,' in L. Sarariva(ed.) History of Mathematical Sciences: Portugal and East Asia IV. Bejing: World Scientific, pp. 203-224.

Stefan, J. (1874), 'Versuch über die scheinbare Adhäsion,' Sitzungsberichte der Mathematisch-naturwissenschaften Klasse der Kaiserlichen Akademie der Wissenschaften, II. Abteilung, vol. 69, Wien: Tempsky, pp. 713-735. [Reprint. Poggendorff's Annalen der Physik, vol. 154.]

Sutherland, W. (1910), 'The mechanical vibrations of atoms,' Phil. Mag., vol. 20, pp. 657-660. https://doi.org/10.1080/14786441008636949

Toynbee, A. (1962), A Study of History, New York: Oxford University Press.

van Zanden, J. L. (2011a), 'Before the Great Divergence: The modernity of China at the onset of the industrial revolution,' VOX CEPR's Policy Portal

van Zanden, J. L. (2011b), Wages, prices, and living standards in China, 1738-1925: in comparison with Europe, Japan, and India,' The Economic History Review, vol. 64, no. 1, pp. 8-38.

Wang, H. (2010), 'Discovering Steam Power in China, 1840s-1860s,' Technology and Culture, vol. 51, no. 1, pp. 31-54. https://doi.org/10.1353/tech.0.0388

Wang, M. C. \& Uhlenbeck, G. E. (1945), 'On the theory of the Brownian motion II,' Rev. Mod. Phys., vol. 17, no. 1, pp 323-342. https://doi.org/10.1103/RevModPhys.17.323

Wang, S. C. (1928), 'The problem of the normal hydrogen molecule in the new quantum mechanics,' Phys. Rev., vol. 31, no. 4, pp. 579-586.

https://doi.org/10.1103/PhysRev.31.579

You, P-L. (2010), 'Atoms can be divided into three categories: polar, non-polar and hydrogen atom,' arXiv:1010.2425 [physics.gen-ph], 10 Oct 2010.

Zhu, Y. \& Liu, L. (2016), Atomistic Simulation of Quantum Transport in Nanoelectronic Devices, Singapore \& Hackensack, NJ: World Scientific. https://doi. org/10.1142/10072 
Stanislav Južnič was born in San Francisco and obtained US and Slovenian citizenship. During his studies he worked at the University of Minsk in Belarus, which enabled him to understand better Augustin Hallerstein's relation with the Russian Academy and Gabriel Gruber's work in Russia. He graduated from the Physics Department and studied the history of eighteenth-century physics with academician Vasilij Melik at the Department of History of the University of Ljubljana. After obtaining his PhD, he returned to USA, where he worked in the Film Library of the Jesuit University Saint Louis, MO, and at the Science Department, University of Oklahoma, researching simultaneously also at the Institute for Mathematics, Physics, and Mechanics in Ljubljana, at the Scientific Research Centre of Slovenian Academy of Sciences and Arts, and as the head of Slovenian Jesuit Archives. He has published about one thousand research works (articles, books) in Chinese, and almost all European languages in China, Japan, USA, Australia, Russia and many European countries. His contemporary research is connected with Rudjer Bošković and Nikola Tesla networks, showing how Tesla's electronics emerged from the ideas of the Jesuit teachers of his teachers.

For decades, he collaborated with Ljubljana Jesuits, trying to highlight the achievements of the Ljubljana Jesuit physicists. Among his recent monographs are the one on Hallerstein, a Chinese astronomer from Mengeš (2003, English translations 2014, Chinese translations 2015 and 2016), and the three-volume History of the Vacuum Research and Vacuum Techniques (2004, 2009, 2016). For the International Year of Astronomy 2009 he finished his trilogy about the history of exact sciences in Slovenia. He prepared the history of Franciscan physics and related sciences for the $800^{\text {th }}$ anniversary of the Franciscan order in 2009. 